\title{
MANAJEMEN PROGRAM PENDIDIKAN KESETARAAN PAKET C DALAM PENINGKATAN MUTU PENDIDIKAN
}

\author{
${ }^{1}$ Lippi Fiqriya Pangestu, ${ }^{2}$ Lulu Yuliani ${ }^{3}$ Yus Darusman \\ Jurusan pendidikan masyarakat, FKIP, Universitas Siliwangi, Tasikmalaya \\ e-mail: ${ }^{1}$ lippi.pangestu09@gmail.com, ${ }^{2}$ luluyuliani@ unsil.ac.id, ${ }^{3}$ yus.darusman@gmail.com
}

\begin{abstract}
Abstrak
Mutu suatu pendidikan dapat mempengaruhi lulusan suatu lembaga persekolahan baik formal maupun nonformal. Manajemen program pendidikan yang dikelola dengan baik akan dapat meningkatkan mutu pendidikan meskipun dalam prosesnya secara bertahap. Tujuan penelitian ini untuk mengetahui bagaimana pengelolaan manajemen kesetaraan paket C di SKB Kota Tasikmalaya dalam meningkatkan mutu pendidikan. Penelitian ini dilakukan karena ditemukan beberapa permasalahan yang dapat mempengaruhi mutu pendidikan, diantaranya peserta didik yang menguasai IT masih sedikit, proses pembelajaran yang tidak terkontrol, penyebaran informasi pembelajaran berbasis ICT belum merata, peserta didik menginginkan pelayanan yang mudah dan cepat, serta sulitnya peserta didik menyesuaikan diri dengan peserta yang lain. Penelitian ini menggunakan metode kualitatif deskriptif yaitu pemecahan masalah yang didapatkan dengan cara mendeskripsikan keadaan objek atau subjek penelitian berdasarkan fakta di lapangan. Sumber data yang digunakan adalah data primer dan data sekunder yang didapatkan dari delapan informan dan data administratif lembaga. Teknik pengumpulan data pada penelitian ini yaitu dengan melalui observasi, wawancara, dan dokumentasi. Instrumen yang digunakan adalah pedoman observasi dan wawancara. Berdasarkan hasil penelitian ditemukan bahwa manajemen program pendidikan kesetaraan paket $\mathrm{C}$ yang meliputi aspek fungsi perencanaan, pengorganisasian, pelaksanaan, pengawasan serta evaluasi, secara keseluruhan telah sesuai dengan apa yang diharapkan dan berjalan secara terstruktur serta telah mencapai tujuan seperti yang diharapkan, yaitu mutu pendidikannya meningkat. Dapat disimpulkan bahwa manajemen program pendidikan kesetaraan paket C di SKB Kota Tasikmalaya secara bertahap dapat meningkatkan mutu pendidikan.
\end{abstract}

Kata Kunci: Manajemen, paket C, Mutu, Pendidikan.

\begin{abstract}
The quality of an education can affect the graduates of a schooling institution, both formal and non-formal. Well-managed education program management will be able to improve the quality of education even though it is through a gradual process proses. The purpose of this research was to find out how the package $C$ equivalence management process at SKB Tasikmalaya City in improving the quality of education. This research was conducted because several problems were found that could affect the quality of education, including only a few students who mastered IT, the learning process was not controlled, the dissemination of information on ICT-based learning was not evenly distributed, students wanted easy and fast services, and the difficulty of students adapting with other participants. This research uses descriptive qualitative methods, which are problem solving obtained by describing the state of the object or research subject based on facts in the field. The data sources used are primary data and secondary data obtained from eight informants and institutional administrative data. Data collection techniques in this study are through observation, interviews, and documentation. The instruments used are observation and
\end{abstract}


interview guidelines. Based on the results of the study, it was found that the management of the package $C$ equivalence education program which includes aspects of planning, organizing, actuating, monitoring and evaluating functions, Overall, it has been in accordance with and is running in a structured manner and has achieved the expected goals. It can be concluded that the management of the package $C$ equivalence education program at the Tasikmalaya City SKB can gradually improve the quality of education.

Keywords: Management, package C, Quality, Education

\section{PENDAHULUAN}

Dalam proses pembelajaran, siswa seringkali ditekankan untuk mengembangkan kemampuan berfikir dan mengesampingkan keahlian/keterampilan. Padahal pada era milenial ini, seiring dengan perkembangan jaman, adanya modernisasi yang ditandai dengan semakin majunya sistem teknologi, komunikasi dan sektor ekonomi. Masyarakat akan bersaing satu dengan yang lainnya untuk mendapatkan pekerjaan dengan menunjukkan keterampilan, pengetahuan dan sikap yang telah dimilikinya. Pendidikan nonformal sebagai pelengkap, penambah, dan pengganti sangat berperan di sini, pendidikan nonformal membantu menemukan jalan keluar dari masalah yang menjadi beban masyarakat diantaranya seperti keterbatasan biaya dan asumsi pendidikan bukan hal segalanya. Pendidikan nonformal didalamnya berupaya untuk dapat meningkatkan pengetahuan, keterampilan, sikap, dan nilai yang dapat secara berjenjang dan berstruktur, mengembangkan kecakapan hidup untuk belajar sepanjang hayat, salah satunya adalah pendidikan kesetaraan. Program kesetaraan terdapat di Pusat Kegiatan Belajar Mengajar (PKBM) dan Sanggar Kegiatan Belajar (SKB). Sanggar Kegiatan Belajar (SKB) merupakan tempat kegiatan pembelajaran masyarakat yang difokuskan pada tempat tertentu Depdikbud (2003, hlm.2).

Fakta terkait rendahnya suatu mutu pendidikan di Indonesia antara lain: 1) menurut Depdikbud, setiap menit empat anak putus sekolah, 2) Menurut data Kemendiknas pada 2010, lebih dari 1,5 juta anak tiap tahun tidak dapat melanjutkan sekolah dan dari sisi kualitas $54 \%$ guru tidak memiliki kualifikasi yang cukup untuk mengajar, dan 13,19\% bangunan sekolah perlu diperbaiki, 3) dikutip dari Teacher employment \& deployment, world bank 2007, 34\% sekolah di indonesia kekurangan guru/tenaga pendidik, 21\% perkotaan, 37\% di pedesaan, 66\% daerah terpencil, 4) menurut Analisis data guru 2009, Ditjen PMPTK 2009, persebaran indeks kualitas guru setengah nilai maksimal dimana nilai maksimal adalah 11, 4) menurut UNESCO 2011 Education Development Index (EDI) berada di posisi ke-69 dari 127 negara. Faktor yang mempengaruhi keberhasilan mutu pendidikan adalah seluruh komunitas sekolah yang menjalankan tanggung jawab serta tugas pokok fungsinya secara efektif dan efisien.

Peningkatan mutu pendidikan secara teknisnya dapat dilakukan melalui pembelajaran. Hidayanto (2002) dalam Anwar (2006, hlm.5) menjabarkan empat pilar pembelajaran, yaitu pengetahuan, keterampilan, kemandirian dan kemampuan untuk menyesuaikan diri dan bekerjasama. Keempat pilar pembelajaran tersebut tidak dapat terpisahkan karena keempatnya saling berkaitan. Program paket $\mathrm{C}$ merupakan salah satu jalan yang memberikan kesempatan kepada warga belajar usia dewasa yang karena berbagai sebab tidak melanjutkan pendidikan. 
Di Kota Tasikmalaya terdapat Sanggar Kegiatan Belajar, yaitu SKB Kota Tasikmalaya yang salah satu didalamnya terdapat program kesetaraan paket A, B, C. Membahas mengenai program kesetaraan, penyelengaaraan program kesetaraan paket $\mathrm{C}$ di SKB Kota Tasikmalaya dirancang untuk membekali para warga belajarnya dengan pengetahuan, keterampilan, sikap, dan kecakapan untuk dimanfaatkan dalam bekerja maupun usaha mandiri. Permasalahan yang muncul dalam situasi ini adalah peserta didik yang menguasai IT masih sedikit, yang berarti kualitas SDM masih rendah, kemudian proses pembelajaran yang tidak terkontrol, penyebaran informasi pembelajaran paket $\mathrm{C}$ berbasis ICT tidak merata, peserta didik menginginkan pelayanan yang mudah dan cepat, serta sulitnya peserta didik menyesuaikan diri dengan peserta yang lain.

Kualitas dan keberhasilan pembelajaran dipengaruhi oleh kemampuan lembaga dalam mengelola sumber daya manusia (SDM). Pengembangan sumber daya manusia harus disesuaikan dengan karakteristik dan potensi-potensi lingkungan dari SDM tersebut. Agar pendidikan dapat menghasilkan Sumber daya manusia yang berkualitas dan handal, maka diperlukan suatu pengelolaan / manajemen pendidikan yang tepat di dalam programnya serta dapat meningkatkan mutu pendidikan didalamnya. Penelitian ini bertujuan untuk Mendeskripsikan bagaimana Proses Manajemen Program Pendidikan Kesetaraan Paket C dalam Meningkatkan Mutu Pendidikan di SKB Kota Tasikmalaya.

\section{KAJIAN TEORI \\ Manajemen}

Manajemen dapat didefinisikan sebagai bekerja dengan individu-individu untuk memutuskan, menguraikan, dan mencapai tujuan organisasi dengan melaksanakan kapasitas dan mengatur fungsi-fungsi perencanaan (planning), pengorganisasian (organizing), penyusunan personalia/kepegawaian (staffing), pengarahan dan kepemimpinan (leading), dan pengawasan (controlling). Handoko (1999, hlm.8).

Perencanaan adalah kumpulan keputusan-keputusan awal yang akan dilaksanakan. Planning adalah suatu proses untuk untuk menentukan Plan (rencana), diproses oleh planner (perencana), dan hasilnya adalah plan (rencana). George R. Terry dalam Hasibuan (1987, hlm.95) Perencanaan adalah memilih dan menghubungkan kebenaran serta membuat dan memanfaatkan praduga mengenai jangka panjang dengan menggambarkan dan merumuskan kegiatan yang diperlukan untuk mewujudkan hasil yang diinginkan. Pengorganisasian menurut Siagian dalam Sudjana (2000, hlm.114), memberikan batasan-batasan pengorganisasian sebagai suatu kesatuan yang tersusun dari kumpulan individu, instrumen, tugas, wewenang dan tanggungjawab, alat dan tenaga ahli sedemikian rupa sehingga menjadikan suatu organisasi yang dapat digerakkan sebagai satu kesatuan dalam mencapai tujuan yang telah di tentukan.

George R. Terry dalam Hasibuan (2004, hlm.183) mengemukakkan pelaksanaan adalah untuk membuat semua anggota kelompok agar mau bekerjasama dan bekerja secara ikhlas serta bersemangat untuk mencapai tujuan sesuai dengan perencanaan dan usaha-usaha pengorganisasian. Menurut Sudjana (2004, hlm.207), fungsi pelaksanaan adalah untuk mewujudkan tingkat penampilan dan partisipasi yang tinggi dari setiap pelaksanaan yang terlibat dalam kegiatan untuk mencapai tujuan yang telah di tetapkan. Menurut Earl P Strong dalam Malayu Hasibuan (2004, hlm.241) Pengendalian/pengawasan adalah proses 
pengaturan berbagai faktor dalam suatu perusahaan, agar sesuai dengan ketetapan-ketetapan dalam rencana. Pengawasan merupakan proses pengamatan dari seluruh kegiatan organisasi guna lebih menjamin bahwa semua pekerjaan yang sedang di lakukan sesuai dengan rencana yang telah ditentukan sebelumnya (Sutomo, 2012, hlm.16). Syamsu Mappa (1984) dalam Djudju Sudjana (2006, hlm.21) Memberikan pengertian bahwa evaluasi program pendidikan di luar sekolah adalah suatu gerakan yang dilakukan untuk memutuskan berhasil dan tidaknya suatu program program pendidikan. Sedangkan Stake (1975) dalam Djudju Sudjana (2006, hlm.21) menguraikan bahwa evaluasi program adalah tindakan untuk menjawab suatu program yang telah, sedang, dan akan diaktualisasikan.

\section{Program Pendidikan Kesetaraan Paket C}

Program adalah suatu rencana yang konkret. Rencana ini konkret karena dalam sebuah program sudah tercantum sasaran, kebijaksanaan, prosedur, maupun anggarannya. Dengan demikian program juga merupakan usaha-usaha untuk mengefektifkan rangkaian tindakan yang harus dilaksanakan menurut bidangnya masing-masing. Program kesetaraan paket $\mathrm{C}$ setara dengan SMA adalah pelayanan pendidikan pada jenjang menengah kejuruan melalui jalur non-formal. Program paket $\mathrm{C}$ merupakan salah satu upaya yang dilakukan oleh pemerintah untuk memberikan kesempatan kepada masyarakat yang karena berbagai sebab tidak melanjutkan pendidikan.

\section{Peningkatan Mutu Pendidikan}

Mutu Pendidikan terdiri dari kata mutu dan pendidikan. Mutu adalah ukuran, baik buruk suatu benda; taraf atau derajat (kepandaian, kecerdasan, dsb). Secara istilah mutu adalah kualitas memenuhi atau melebihi harapan pelanggan. Mutu pendidikan sangat tergantung dari program pendidikan yang dilaksanakan. Dengan demikian mutu adalah tingkat kualitas yang sudah memenuhi atau dapat dikatakan telah melebihi dari apa yang diharapkan.

\section{Manajemen Berbasis Sekolah}

Manajemen adalah sinkronisasi dan penyerasian sumber daya melalui beberapa input manajemen untuk menggapai tujuan atau untuk memenuhi kebutuhan pelanggan. Berbasis berarti "berdasarkan pada" atau "berfokuskan pada". Sekolah adalah organisasi terbawah dalam runtutan Departemen Pendidikan Nasional (Depdiknas) yang bertugas memberikan bekal kemampuan dasar kepada peserta didik atas ketentuan yang bersifat legalistik dan profesionalistik. Nurkolis (2006, hlm.11), mengemukakkan Manajemen Berbasis Sekolah (MBS) adalah model pengelolaan sekolah dengan memberikan kewenangan yang lebih kepada tingkat sekolah untuk mengelola sekolahnya sendiri secara langsung.

\section{METODE PENELITIAN}

Metode pada penelitian ini yaitu menggunakan metode penelitian kualitatif. Metode ini digunakan oleh peneliti pada penelitian ini dikarenakan permasalahan yang diteliti sifatnya kompleks dan dapat berubah-ubah (dinamis) sehingga tidak mungkin dijaring dengan menggunakan metode kuantitatif. Kemudian penggunaan metode kualitatif juga 
dimaksudkan agar memahami proses manajemen kesetaraan paket $\mathrm{C}$ di SKB Kota Tasikmalaya secara mendalam.

Subjek dalam penelitian ini, Peneliti memilih subjek utama delapan informan, yaitu; Kepala SKB, pengelola/koordinator paket $\mathrm{C}$, tiga tutor, dan tiga warga belajar dari program kesetaraan paket $\mathrm{C}$ sebagai sumber informan user (pengguna) yang dipilih secara acak. Adapun teknik pengumpulan data dalam penelitian ini yaitu data yang dibutuhkan pada penelitian ini disesuaikan dengan kebutuhan seperti; pengamatan/observasi, wawancara, dan dokumentasi. Model analisis data yang dipakai pada penelitian ini menggunakan model Miles yang digambarkan sebagai berikut :

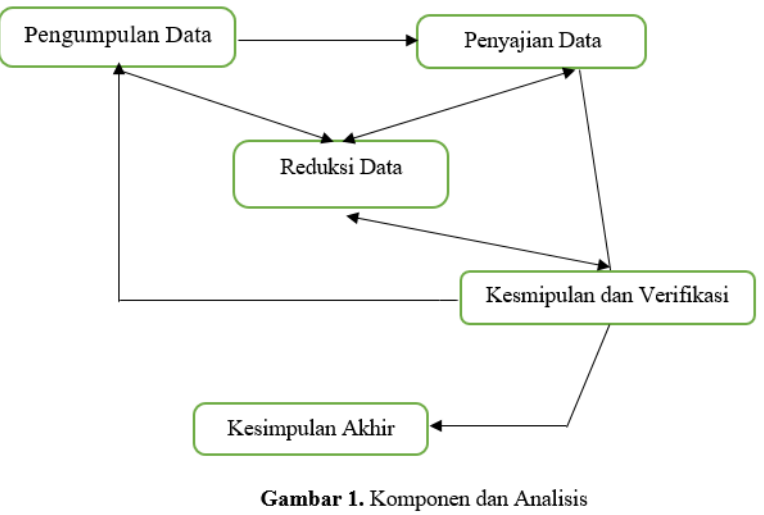

\section{HASIL DAN PEMBAHASAN \\ Perencanaan Program Pendidikan Kesetaraan Paket C dalam Peningkatkan Mutu Pendidikan}

Dari temuan hasil penelitian pada tahap perencanaan pendidikan kesetaraan paket C SKB Kota Tasikmalaya diantaranya adalah merencanakan; penyusunan kepengurusan, merencanakan kurikulum yang akan digunakan; dari KTSP menjadi kurikulum 2013, kemudian menyusun program-program yang akan berjalan, merencanakan jadwal pelajaran; terlaksananya pembelajaran sebanyak 1 minggu 3x dari yang sebelumnya 1 minggu 2x, menentukan metode pembelajaran seperti metode ceramah, tutorial, dan praktik yang dilakukan dengan secara inovatif sehingga warga belajar dapat memahami pembelajaran dengan baik, strategi inquiry dengan student center, selanjutnya media dan sumber belajar yang akan digunakan, merekrut tutor yang siap mengajar dan lulusan yang linear; menjadi 14 tutor dari sebelumnya 7 tutor, menentukan sasaran warga belajar yang membutuhkan pendidikan, merencanakan pembuatan silabus dan RPP dilakukan setiap satu semester untuk silabus dan satu minggu untuk RPP, dan fasilitas yang tersedia termanfaatkan dengan baik oleh warga belajarnya seperti papan tulis, meja, infocus, perpustakaan.

Sebelumnya SKB tidak menerapkan MBS, timbulah permasalahan dalam kemudahan pelayanan. MBS bertujuan untuk memberdayakan sekolah dan masyarakat agar tidak perlu menunggu perintah dari pusat, bahwa SKB dapat membuat visi instruktif disesuaikan dengan kondisi dan melaksanakan visi dengan mandiri dan bebas. Sebelumnya perencanaan 
pembelajaran berbasis IT hanya untuk kursus saja, menyebabkan pembelajaran IT tidak merata, sekarang pembelajaran IT sudah diterapkan di kelas 12, upaya pemerataan mulai terlihat.

Manajemen dapat dikatakan telah ada, jika rencana / tujuannya ada. Maksud dari perencanaan, menurut Hasibuan (2004, hlm.95) adalah untuk menentukan tujuan atau kebijakan, memperkecil resiko yang dihadapi pada masa yang akan datang, mengatur kegiatan, serta memberi gambaran yang jelas dan lengkap tentang keseluruhan tugas/ pekerjaan. Artinya perencanaan membantu dalam peningkatan daya guna, dan daya hasil guna sebuah organisasi.

\section{Pengorganisasian Program Pendidikan Kesetaraan Paket C dalam Peningkatan Mutu Pendidikan}

Dari hasil penelitian terlihat bahwa tugas-tugas yang dimiliki oleh seluruh elemen yang ada di kesetaraan paket $C$ seperti Kepala SKB, pengelola paket C,staf tata usaha, tutor serta warga belajarnya memiliki tugas pokok dan fungsinya masing-masing, sehingga dalam mencapai tujuan akan terlaksana dengan lebih efisien. Kepala SKB secara umum memiliki tugas melaksanakan visi, misi, dan tujuan SKB, menyusun rencana kerja jangka menengah yang menunjukkan tujuan peningkatan mutu pendidikan, mengelola sistem informasi dengan memanfaatkan teknologi, mengembangkan dan mengelola pendidik serta tenaga pendidik, memonitoring, mengevaluasi, dan pelaporan pelaksanaan kegiatan program, melakukann cooperative relation dengan orangtua peserta didik dan dewan pendidikan, melaksanakan pengendalian internal, melaporkan hasil pelaksanaan kepada kepala dinas. Staf Tata usaha mengurus seluruh kegiatan administratif lembaga seperti keluar masuk anggaran serta surat menyurat. Tutor bertugas untuk mengajar, mengendalikan, dan mengevaluasi kegiatan kelas bersama dengan warga belajar yang tugasnya hanyalah belajar secara sungguh-sungguh dan mntaati peraturan yang ada.

Menurut Louis A. Allen dalam Hasibuan Malayu (2015, hlm.119) kita dapat mengartikan organisasi sebagai proses memutuskan dan pengelompokkan tugas yang akan dijalankan, memilih dan memberikan kekuasaan dan kewajiban, dengan tujuan agar memungkinkan individu bekerjasama secara efektif dalam mencapai tujuan. Jadi, Organisasi hanya merupakan sebuah wadah saja. Menurut Manullang dalam Hasibuan Malayu (2015, hlm.119) organisasi dalam arti luas (pengorganisasian) adalah suatu proses pemantapan dan pembagian pekerjaan yang akan dijalankan, membatasi tugas dan tanggungjawab serta kekuasaan/otoritas dan penentuan hubungan antara unsur organisasi, akhirnya mengharuskan orang-orang cakap bekerja sama secara efektif untuk mencapai tujuan. Secara singkat organisasi adalah pembedaan/pembagian tugas.

Mansoer (1989, hlm.96) Pengorganisasian dikenal sebagai fungsi yang mengatur penentuan tugas-tugas yang akan diemban, siapa yang akan menjalankannya, bagaimana berjalannya, siapa yang harus memberi laporan kepada siapa, dan dimana keputusan harus diambil.

\section{Pelaksanaan Program Pendidikan Kesetaraan Paket C dalam Peningkatan Mutu Pendidikan}


Dalam pelaksanaan, jika dilihat dari hasil penelitian, setiap kegiatan dan aspek yang telah direncanakan sebelumnya dan penugasan untuk seluruh elemen di SKB Kota Tasikmalaya telah berjalan sesuai dengan yang diharapkan sesuai dengan tupoksi dan tanggung jawab masing-masing secara efektif dan efisien. Terlihat dari pelaksanaan kurikulum dan pelaksanaan program yang telah berjalan sesuai dengan silabus dan rencana pembelajaran yang telah dirancang sebelumnya, kemudian telah diteapkannya MBS semakin mempermudah pelayanan kepada pelanggan SKB, SKB dapat membuat keputusan mandiri yang sesuai dengan keadaan selama tidak menyeleweng. Kemudian penggunaan media belajar dan fasilitas yang tepat untuk warga belajar, modul pembelajaran dan bahan ajar telah sesuai; sekarang dengan e-modul, maupun kehadiran tutor dalam setiap kegiatan pembelajaran tepat pada waktunya yang awalnya sebanyak $2 \mathrm{x}$ menjadi $3 \mathrm{x} / \mathrm{ming}$ gu dan sepuluh patokan DIKMAS pun telah terpenuhi dengan baik di SKB ini khususnya pada program paket $\mathrm{C}$. Jika pelaksanaan pembelajaran kesetaraan paket $\mathrm{C}$ telah berjalan dengan baik dan memenuhi seluruh kebutuhan warga belajarnya maka dapat dikatakan mutu pendidikan di SKB Kota Tasikmalaya telah meningkat.

Pembelajaran berbasis ICT (Information Communication Technology) masih dalam pemerataan oleh pihak SKB untuk paket C, diharapkan semakin mempermudah proses pembelajaran. Sesuai dalam karakteristik peningkatan mutu pendidikan, segala sesuatu yang ada di SKB telah merujuk dan mengupayakan ke arah yang lebih baik.

Menurut Sudjana (2004, hlm.207), fungsi pelaksanaan adalah untuk mewujudkan tingkat penampilan dan partisipasi yang tinggi dari setiap yang terlibat dalam kegiatan untuk mencapai tujuan yang di tetapkan. Pada pelaksanaan, setiap orang yang terlibat dan telah ditentukan pekerjaannya dalam pembagian tugas pada fungsi pengorganisasian, hendaknya berpartisipasi penuh dalam pelaksanaannya di lapangan, sehingga tujuan yang telah ditentukan sebelumnya bisa tercapai.

Menurut Siagian dan Sutomo (2012, hlm.14) mendefinisikan actuating sebagai keseluruhan usaha, upaya, teknik, cara dan metode untuk mendorong para anggotanya agar mau bekerja dengan seoptimal mungkin untuk tercapainya tujuan organisasi dengan efektif, efisien, dan ekonomis. Fungsi manajemen yang paling dominan adalah pelaksanaan, fungsi ini baru dapat berjalan setelah adanya rencana, organisasi, serta karyawan. Fungsi pelaksanaan merupakan tindak realisasi dari tujuan/ rencana.

\section{Pengawasan Program Pendidikan Kesetaraan Paket C dalam Peningkatan Mutu Pendidikan}

Fungsi pengawasan pada program kesetaraan paket C dilakukan oleh kepala SKB dan pengelola kesetaraan paket C. Pengawasan dilakukan secara internal dan eksternal. Seperti yang dikemukakkan oleh Malayu Hasibuan (2004, hlm.248) Pengawasan secara internal merupakan suatu pengawasan yang dilakukan oleh seorang atasan kepada bawahannya. Yaitu Kepala SKB dan pengelola kesetaraan paket C memastikan bahwa semua yang dijalankan sesuai dengan acuan yang telah direncanakan, seperti; mengecek kehadiran dan kinerja tutor, kinerja staf, serta kegiatan yang sedang berlangsung, kemudian menilai, menganalisis yang berkaitan dengan bidang pekerjaan yang ada di lingkungan SKB Kota Tasikmalaya. Pengawasan internal lain yang dilakukan oleh pengelola kesetaraan paket $\mathrm{C}$ yaitu, memantau jalannya pembelajaran kesetaraan paket $\mathrm{C}$ yang berlangsung bersama tim, 
kemudian dikoordinasikan laporan hasilnya kepada kepala SKB. Jika sebelumnya pengawasan internal dilakukan setiap akhir semester, namun dalam upaya meningkatkan kedisiplinan pemangku jabatan untuk meningkatkan mutu pendidikan, pengawasan ditingkatkan menjadi dua bulan sekali.

Pengawasan secara eksternal merupakan suatu pemeriksaan yang dijalankan oleh orang atau badan yang berada diluar unit sekolah, SKB Kota Tasikmalaya dipantau dan diperiksa oleh penilik dari dinas maupun dari pusat. Aspek yang diawasi diantaranya yaitu aspek administrasi SKB, tupoksi kepala, tupoksi pamong, serta tupoksi staf-staf lain. kemudian penilaian dari masyarakat sekitar terhadap lembaga SKB. Proses pengawasan yang dilakukan secara rutin akan membantu pihak SKB untuk mempermudah mencatat kinerja dan pengamatan pelaksanaan seluruh kegiatan untuk menjmin agar semua yang telah dikerjakan berjalan sesuai dengan perencanaan yang telah ditentukan.

G.R Terry dalam Hasibuan Malayu (2004, hlm.242) pengendalian / pengawasan dapat didefinisikan sebagai proses penentuan standar, pelaksanaan, menilai pelaksanaan dan jika perlu melakukan perbaikan-perbaikan, sehingga pelaksanaan sesuai dengan rencana. Fungsi pengawasan pada program kesetaraan paket $C$ dilakukan oleh kepala SKB dan pengelola kesetaraan paket C. Pengawasan dilakukan secara internal dan eksternal.

Earl P. Strong dalam Hasibuan Malayu (2004, hlm.241) Controlling is the process of regulating the various factors in a enterprise according to the requirement of its plans.

Pengendalian merupakan proses mengatur faktor-faktor yang ada dalam suatu lembaga agar dalam pelaksanaannya dapat berjalan sesuai dengan ketetapan yang ada dalam rencana.

\section{Evaluasi Program Pendidikan Kesetaraan Paket $\mathrm{C}$ dalam Peningkatan Mutu Pendidikan}

Evaluasi dilakukan untuk mengetahui tingkat pencapaian pelaksanaan suatu kegiatan apakah sudah sesuai dengan rencana yang ditetapkan ataukah telah terjadi pergeseran dari sisi rencana. Dengan demikian dapat ditemukan tentang langkah-langkah atau arah tujuan target dimasa yang mendatang dan mengambil pelajaran dari yang sudah terjadi sebelumya.

Aspek yang di evaluasi dalam program kesetaraan paket $\mathrm{C}$ adalah aktivitas warga belajar dan aktivitas tutor serta partisipasinya dalam setiap kegiatan pembelajaran dengan cara evaluasi sumatif dan formatif. Penilaian formatif adalah dimana evaluasi dilakukan setiap setelah berakhirnya pembelajaran yang bisa digunakan sebagai bahan informsi perbaikan proses mengajar untuk mengetahui sampai dimana warga belajar menguasai materi yang diajarkan selama pelaksanaan pembelajaran dalam kelas. Sedangkan penilaian sumatif adalah penilaian hasil belajar jangka panjang, artinya penilaian yang dilaksanakan pada akhir tahun ajaran dari keseluruhan kegiatan pembelajaran, hasilnya berupa laporan kepada orang tua. Setelah dilakukan evaluasi, akan diketahui tingkat kelulusan yang mencapai $100 \%$, banyaknya lulusan yang memiliki keterampilan dan pengetahuan, banyaknya lulusan yang jadi memiliki pekerjaan yang lebih baik, bahkan ada beberapa lulusan yang menciptakan lapangan pekerjaan. Hal tersebut menjadi bukti pendidikan telah berhasil menciptakan output yang berkualitas.

Syamsu Mappa (1984) dalam Djudju Sudjana (2006, hlm.21) mendefinisikan bahwa evaluasi program pendidikan luar sekolah sebagai tindakan yang dilakukan untuk 
memutuskan keberhasilan dan kegagalan suatu program pendidikan. Sedangkan Stake (1975) dalam Djudju Sudjana (2006, hlm.21) menggambarkan bahwa evaluasi program adalah kegiatan untuk merespon suatu program yang telah, sedang, dan akan dilaksanakan. Stake mengemukakan bahwa evaluasi program pendidikan berorientasi langsung pada kegiatan dalam pelaksanaan program dan evaluasi dilakukan untuk merespon pihak-pihak yang membutuhkan informasi mengenai program tersebut.

\section{SIMPULAN}

1. Pada tahap perencanaan, kesetaraan paket C di SKB Kota Tasikmalaya melakukan penambahan tutor bantu yang sesuai dengan kualifikasi pendidikan yang linear sehingga tutor dapat memberikan pembelajaran lebih mendetail dan warga belajar menjadi lebih memahami apa yang disampaikan oleh tutor. Metode ceramah menjadi metode tanya jawab dengan strategi inquiry dan student centre. Sebelumnya SKB belum menerapkan sistem MBS, sekarang sudah menerapkan MBS.

2. Pengorganisasian pada program pendidikan kesetaraan paket $\mathrm{C}$ di SKB Kota Tasikmalaya dengan penentuan tugas-tugas dari Kepala SKB, tutor, tugas staf tata usaha, tugas pengelola kesetaraan paket $\mathrm{C}$, dan warga belajar berjalan beriringan sehingga tercapainya tujuan yang diinginkan untuk upaya perbaikan ke arah peningkatan mutu pendidikan.

3. Pelaksanaan pada program pendidikan kesetaraan paket C di SKB Kota Tasikmalaya meningkat. Pelayanan menjadi mudah karena MBS diterapkan, penambahan tutor bantu berkualifikasi, penyesuaian metode dan strategi belajar meskipun saat pandemi, pembelajaran berbasis ICT untuk kesetaraan telah diterapkan, pelaksanaan pembelajaran meningkat $2 x /$ minggu menjadi $3 x /$ minggu.

4. Pengawasan pada program pendidikan kesetaraan paket C di SKB Kota Tasikmalaya meningkat. Awalnya setiap semester menjadi secara rutin 2x/bulan untuk mempermudah SKB dalam pencatatan kinerja dan pengamatan pelaksanaan seluruh kegiatan yang berlangsung untuk menjamin semua yang berjalan sesuai dengan perencanaan yang telah ditentukan sbeelumnya.

5. Evaluasi pada program pendidikan kesetaraan paket C di SKB Kota Tasikmalaya dapat mengetahui tentang pencapaian target dimasa mendatang dan mengambil pelajaran dari yang sudah terjadi sebelumya. Kelulusan warga belajar 100\%, selain pengetahuan, lulusan juga dibekali keahlian, lulusan mendapat pekerjaan lebih baik, dan ada lulusan yang menciptakan lapangan pekerjaan

6. Dilihat dari komponen dan karakteristik Peningkatan Mutu Pendidikan sebagai tolak ukur, secara keseluruhan Kesetaraan Paket C SKB kota Tasikmalaya telah memenuhi dan dapat dikatakan; proses manajemen yang baik dapat meningkatkan mutu pendidikan

\section{SARAN}

1. Mengoptimalkan peran dan fungsi SKB, mengembangkan pembelajaran dengan baik, dan meningkatkan, mengembangkan program yang inovatif dan kreatif erta menjalin kerjasama dengan lembaga lain.

2. Segera merealisasikan pembelajaran berbasis teknologi kepada warga belajar paket $\mathrm{C}$ secara merata untuk kelangsungan pendidikan yang lebih maju. 
3. Dari setiap kegiatan yang telah berjalan, hal yang perlu di diperhatikan adalah peningkatan sumber daya manusianya seperti Kepala, tutor maupun staf. Dapat ditingkatkan dengan mengupayakan pemerintah daerah untuk mengadakan pelatihan dan pengembangan karier bagi seluruh pendidik maupun tenaga pendidik di SKB Kota Tasikmalaya.

\section{DAFTAR PUSTAKA}

Amirullah, dan Hanafi. (2002). Pengantar Manajemen, Edisi Pertama, Cetakan Pertama. Yogyakarta: Graha Ilmu.

Direktorat, Dikmenum. (2000). Manajemen Peningkatan Mutu Berbasis Sekolah. Jakarta: Depdiknas.

Djudju Sudjana. (2004). Manajemen Program Pendidikan untuk Pendidikan Nonformal dan Pengembangan Sumber Daya Manusia. Bandung : Falah Production. . (2006). Manajemen Program Pendidikan untuk Pendidikan Luar Sekolah dan Pengembangan Sumberdaya Manusia. Bandung: Falah Production.

Hamid, hamid. (2018). Manajemen berbasis sekolah. Al-khwarizmi: Jurnal Pendidikan Matematika dan Ilmu Pengetahuan Alam. Journal electronic. Vol 1. Hal 87-96. 10.24256/jpmipa.v1i1.86. Retrieved from https://www.researchgate.net/publication/328635158

Hasibuan, Malayu. (1987). Manajemen: Dasar, Pengertian, dan Masalah. Jakarta: Haji Masagung.

. (2004). Manajemen: Dasar, Pengertian, dan Masalah. Edisi Revisi, Cet3. Jakarta: Bumi Aksara.

Mansoer, H, Hamdan. (1989) Pengantar Manajemen. Jakarta: Depdikbud.

Mulyasa, E. (2002). Manajemen Berbasis Sekolah. Bandung: PT Remaja Rosdakarya

Sugiyono. (2011). Metode penelitian Pendidikan. pendekatan kuantitatif, kualitatif, dan $R \& D$. Cet-7. Bandung: Alfabeta.

Sutomo, dkk. (2012). Manajemen sekolah, edisi revisi, cetakan kesembilan. Semarang: UNNES PRESS

T, Hani. Handoko. (1999). Manajemen, Edisi 2. Yogyakarta. BPFE UGM 